\title{
Related Subunits of NF-kB Map to Two Distinct Loci Associated with Translocations in Leukemia, NFKB1 and NFKB2
}

\author{
Susanne Liptay, ${ }^{*}$ Roland M. Schmid, ${ }^{\star}$ Neil D. Perkins, ${ }^{*}$ Paul Meltzer, $†$ Michael R. Altherr, $\ddagger$ \\ JOHN D. MCPHERSON, $\ddagger$ JOHN J. WASMUTh, $\ddagger$ AND GARY J. NABEL ${ }^{1, *}$ \\ *Howard Hughes Medical Institute, Departments of Internal Medicine and Biological Chemistry, and tDepartment of Pediatrics \\ and Radiation Oncology, University of Michigan Medical Center, Ann Arbor, Michigan 48109-0650; \\ and $¥$ Department of Biological Chemistry, University of California, Irvine, California 92717
}

Received September 9, 1991; revised December 31, 1991

The chromosomal locations of the human genes NFKB1 and NFKB2, which encode two alternative DNA binding subunits of the NF- $k B$ complex, 105 and $49 / p 100$, respectively, have been determined. p105 was assigned to 4q21.1-q24 and p49/ p 100 to chromosome 10 by Southern blot analysis of panels of human/Chinese hamster cell hybrids. 'The locations were confirmed by fluorescence in situ hybridization and mapped with greater resolution to $4 \mathrm{q} 23$ and $10 \mathrm{q} 24$, respectively. These results demonstrate that these members of the NF- $\mathrm{BB}$ family are unlinked. Interestingly, $\mathrm{p49/p100}$ as well as p105 maps to regions associated with certain types of acute lymphoblastic leukemia. 1992 Academic Press, Inc.

\section{INTRODUCTION}

The transcription factor NF- $\kappa$ B comprises a multicomponent protein complex that plays a major role in the regulation of many viral and cellular genes. First described as an 11-bp cis-acting sequence in the immunoglobulin light-chain enhancer (Sen and Baltimore, $1986 a)$, related sites have been described in a variety of other genes, including viral (Nabel and Baltimore, 1987; Boshart et al., 1985) and other cellular genes (Leung and Nabel, 1988; Böhnlein et al., 1988; Ruben et al., 1988; Israël et al., 1989; Lenardo and Baltimore, 1989). Many of these cellular target genes of NF- $\kappa \mathrm{B}$ are involved in the regulation of immunological functions. NF- $\kappa \mathrm{B}$ activity is constitutively present in mature B cells (Sen and Baltimore, 1986a) and macrophages (Griffin et al., 1989) and can be activated in 'T cells and nonlymphoid cells by endogenous and exogenous stimuli (Sen and Baltimore, 1986b; Nabel and Baltimore, 1987; Griffin et al., 1989; Osborn et al., 1989). The active NF- $\kappa \mathrm{B}$ complex is formed in the cytoplasm after the dissociation of an inhibitory protein, $\mathrm{I}_{\kappa} \mathrm{B}$, and consists of a $50-\mathrm{kDa}$ and a $65-\mathrm{kDa}$ subunit which are translocated to the nucleus (Baeuerle and Baltimore, 1988a,b).

\footnotetext{
${ }^{1}$ To whom correspondence should be addressed.
}

Recently NF- $\kappa$ B genes have been isolated and found to be related to the maternal effect gene dorsal and to the oncogene c-rel (Kieran et al., 1990; Ghosh et al., 1990; Bours et al., 1990; Schmid et al., 1991; Ruben et al., 1991; Ryseck et al., 1992). One 50-kDa DNA binding subunit was presumed to be synthesized from a $105-\mathrm{kDa}$ precursor which would require proteolytic processing (Kieran et al., 1990; Ghosh et al., 1990). An alternative DNA binding subunit can also be generated in the same way from a second independent gene product of $100 \mathrm{kDa}$ or as an alternatively spliced form of this gene (Schmid et al., 1991). p100 and p105 are highly homologous in both $\mathrm{N}$ and $\mathrm{C}$ termini. Another subfamily is defined by c-rel and p65 (Schmid et al., 1991), which contain putative transactivation domains at their $\mathrm{C}$ termini. Alignment of their sequences reveals highly conserved subregions, which are thought to participate in DNA binding and dimerization. So far, five independent cDNAs that encode gene products related to the $\mathrm{NF}-\mathrm{kB}$ complex have been cloned, giving rise to a multigene family (Schmid et al., 1991). Among the members of the $\mathrm{NF}-\kappa \mathrm{B} / \mathrm{rel} / \mathrm{dorsal}$ family, only the human c-rel gene has been previously localized, to chromosome 2p12-2p13 (Brownell et al., 1988). To investigate the relationship between NF- $\mathrm{B}$ $\mathrm{p} 49 / \mathrm{p} 100, \mathrm{NF}-\kappa \mathrm{B}$ p105, and $\mathrm{c}$-rel further, and to analyze the possible correlation to pathological conditions, the chromosomal localization of $\mathrm{p} 49 / \mathrm{p} 100$ and $\mathrm{p} 105$ was determined.

\section{MATERIALS AND METHODS}

Screening of a human genomic phage library. A human genomic library in Charon 4A, kindly provided by Dr. David Kurnit, was screened with a 420-bp EcoRl/BglII cDNA fragment from p49/p100 (Schmid et al., 1991) and a 1.2-kb EcoRI/Spel cDNA fragment from p105 (Kieran et al., 1990). Phage were plated at approximately 30,000 plaques $/ 15-\mathrm{cm}$ plate. Nitrocellulose filters were lifted in duplicate. Filters were denatured in $0.5 \mathrm{M} \mathrm{NaOH}, 1.5 \mathrm{M} \mathrm{NaCl}$ for $1 \mathrm{~min}$, neutralized in $1 M$ Tris, pH 7.4, 1.5 M NaCl for $4 \mathrm{~min}$, and soaked in $3 \times \mathrm{SSC}$ for up to $10 \mathrm{~min}$. DNA was UV-crosslinked for $0.7 \mathrm{~min}$ at $0.12 \mathrm{~J}$ with a Stratalinker apparatus. Filters were prehybridized in $6 \times$ SSPE, $5 \times$ Denhardt solution, $100 \mu \mathrm{g} / \mathrm{ml}$ salmon sperm DNA, $0.1 \%$ SDS for $2 \mathrm{~h}$ 
at $55^{\circ} \mathrm{C}$ and hybridized by adding $2 \times 10^{6} \mathrm{cpm} / \mathrm{ml}$ random primer-labeled probe (sp act $5 \times 10^{8} \mathrm{cpm} / \mu \mathrm{g}$ ) (Feinberg and Vogelstein, 1983) for $12-14 \mathrm{~h}$ at $65^{\circ} \mathrm{C}$. Filters were washed with a final stringency of $0.2 \times \mathrm{SSC}, 0.1 \% \mathrm{SDS}$ at $65^{\circ} \mathrm{C}$. After screening of approximately $7.2 \times$ $10^{5}$ plaques, seven independent genomic p49/p100 clones and eight independent genomic p105 clones were isolated. DNA was prepared from plaque-purified phage and further characterized by restriction enzyme mapping and Southern blot analysis (modified as described by Smith and Summers, 1980). A 5.5-kb HindIII fragment of genomic p49/p100, clone p100.G25, and a 7.1-kb EcoRI fragment of genomic p105, clone p105.G2, were subcloned into the Bluescript $\mathrm{SK}+/-$ plasmid (Stratagene) and partially sequenced using the Sequenase protocol (United States Biochemical Corp.).

Isolation of the p105 and p49/p100 cDNAs. Isolation of full-length p105 and p49/p100 cDNAs has been described previously (Schmid et al., 1991).

Somatic cell hybrids. Chromosomal localization of p49/p100 was carried out by Southern blot analysis of a panel of 24 human/Chinese hamster cell hybrids (Fig. 1). Each of the hybrids used contains from one to three human chromosomes and collectively allow assignment of a marker to any one of the 24 distinct human chromosomes (Scherer et al., 1992). The chromosomes retained by each of the cell hybrids are shown in Fig. 1. The probe used in the mapping experiment was the whole cDNA clone of $\mathrm{p} 49$ described previously (Schmid et al., 1991). DNA from the cell hybrids, human cells, and Chinese hamster cells was digested to completion with $E c o$ RI and subjected to Southern blot analysis as described previously (Altherr et al., 1989).

Regional localization of $\mathrm{p} 105$ on chromosome 4 was carried out by Southern blot analysis of a panel of human/Chinese hamster cell hybrids. One of these hybrids, HHW 416, contains an intact chromosome 4 as its only human DNA (Carlock et al., 1986). Each of the other six cell hybrids retains a naturally occurring deleted or translocated chromosome 4 (Tabas et al., 1991; Altherr et al., 1989). The probe used in the mapping experiments was a 564-bp $\mathrm{XbaI}$ fragment derived from the $\mathrm{C}$-terminal coding region of p105 cDNA. DNA from the cell hybrids, human cells, and Chinese hamster cells was digested to completion with HindIII and subjected to Southern blot analysis as described previously (Altherr et al., 1989).

Fluorescence in situ hybridization (FISH). A p49/p100 genomic clone with an approximately $15-\mathrm{kb}$ insert, p100.G25, and a p105 genomic clone of approximately $20 \mathrm{~kb}$, p105.G2, were used for FISH. Probes were biotin-labeled by nick translation using the Bio-Nick kit as recommended by the manufacturer (BRL, Gaithersburg, MD). Metaphase spreads of peripheral blood lymphocytes were G-banded, photographed, and then destained (Klever et al., 1991). FISH was then carried out with the biotinylated probe according to the method of Pinkel et al. (1986).

\section{RESULTS}

\section{Isolation of Human Genomic p49/p100 and p105}

Probes prepared from cDNAs encoding the NF- $k \mathrm{~B}$ subunits p49/p100 and p105 were used to screen human genomic libraries at high stringency. A total of seven clones for $\mathrm{p} 49 / \mathrm{p} 100$ and eight clones for $\mathrm{p} 105$ were isolated and plaque purified. Several clones were characterized by restriction enzyme mapping, Southern blotting, and DNA sequence analysis. The phage insert sizes ranged between 14 and $20 \mathrm{~kb}$. A clone of $\mathrm{p} 49 / \mathrm{p} 100$ containing an approximately $15-\mathrm{kb}$ insert, p100.G25, and a p105 clone with an approximately 20 -kb insert, p105.G2, were used for FISH, respectively.

Chromosomal Assignment of p49/p100 Using Somatic

\section{Cell Hybrids}

Figure 1 shows the assignment of $\mathrm{p} 49 / \mathrm{p} 100$ to chromosome 10. In addition to total human DNA (lane 26), human-specific hybridization of the $\mathrm{p} 49 / \mathrm{p} 100$ probe was observed only to DNA from the hybrid cell line HHW983. This cell line contains only human chromosomes 5 and 10 in addition to the Chinese hamster genome. Since DNA from cell line HHW105 (lane 6) and all other hybrids which contain a human chromosome 5 clearly do not show human-specific hybridization to the p49/p100 probe, this locus has been assigned to human chromosome 10.

\section{Chromosomal Localization of p49/p100 by Fluorescence in Situ Hybridization}

A genomic p49/p100 clone, p100.G25 was localized to human metaphase chromosomes by FISH analysis. Twenty-five cells were examined. Fluorescence hybridization signals were observed in 13 cells $(52 \%)$. Of the hybridization signals observed, $97 \%$ localized specifically to chromosome 10 . Fluorescence signals were observed on both homologs of chromosome 10 in $8 / 13$ cells, and in $5 / 13$ cells, only one homolog gave a signal for a total of 21 chromosomes analyzed. Of thesc 21 chromo somes, the majority demonstrated hybridization to both chromatids ( $38 / 42$ chromatids). The procedure utilized allowed for G-banding of the same mitoses used for FISH analysis, permitting unequivocal localization of fluorescent signals. All 38 of the specific hybridization signals observed localized to the band 10q24 (Figs. 2A and $\mathrm{B}$ ).

\section{Chromosomal Assignment of p105 Using Somatic Cell Hybrids}

Southern blot analysis of a human chromosome mapping panel (Tabas et al., 1991) using a fragment of the p105 cDNA as a probe revealed $100 \%$ concordance between human chromosome 4 and a specific HindIII restriction fragment detected by the probe (data not shown). This result was confirmed and the gene encoding p105 was regionally localized on chromosome 4 by similar analysis of a panel of seven additional cell hybrids which retain specific segments of chromosome 4 . These results are summarized in Fig. 3. A human-specific HindIII restriction fragment revealed by the p105 probe is present in HHW 416 (intact chromosome 4), HHW 848, HHW 886, HHW 892, and HHW 842 but is missing in HHW 986, HHW 582, and HHW 693. These results demonstrate that $\mathrm{p} 105$ is located at $4 \mathrm{q} 21.1-4 \mathrm{q} 24$.

\section{Chromosomal Localization of p105 by Fluorescence in Situ Hybridization}

A genomic p105 clone, p105.G2, was hybridized to normal metaphase chromosomes by FISH analysis. Fluorescence signals were observed in 15 cells; all 15 cells demonstrated specific hybridization. Fluorescence signals were observed on both homologs of chromosome 4 in 10 of 15 cells, and in 5 of 15 cells, only one homolog demonstrated hybridization. Of these 25 chromosomes with fluorescence hybridization, most exhibited hybrid- 


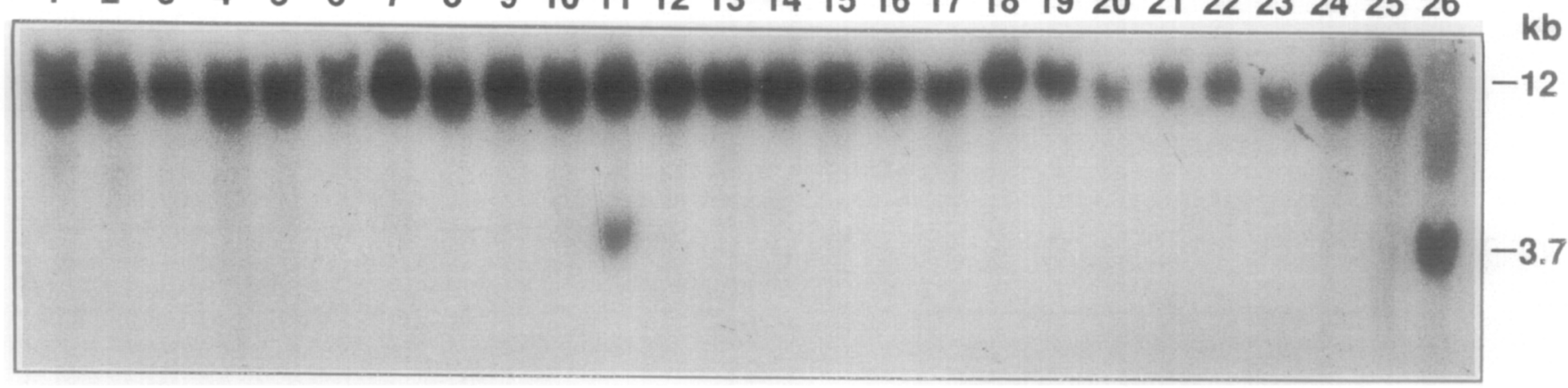

\begin{tabular}{|c|c|c|c|c|c|c|c|c|c|c|c|c|c|c|c|c|c|c|c|c|c|c|c|c|c|c|}
\hline & & & & & & & & & & & Ch & om & oso & me & $s \mathbf{P r}$ & rese & & & & & & & & & & \\
\hline Lane & Cell Line & 1 & 2 & 3 & 4 & 5 & 6 & 7 & 8 & 9 & 10 & 11 & 12 & 13 & 14 & 15 & 16 & 17 & 18 & $1 9 \longdiv { 2 }$ & 20 & 212 & 22 & $\underline{x}$ & $Y$ & Comments \\
\hline 1 & UCW104 & & & & & & & & & & & & & & & & & & & & & & & & & СHO \\
\hline 2 & HHW1144 & $*$ & & & & * & & & & & & & & & & & & & & & & & & & & \\
\hline 3 & HHW1164 & & $*$ & & & & & & & & & & & & & & & & & & & & & * & & 2 in $66 \%$ of celle \\
\hline 4 & HHW342 & & & * & & * & & & & & & & & & & & & & & & & & & & & del(5)(p 14.2) \\
\hline 5 & HHW416 & & & & * & & & & & & & & & & & & & & & & & & & & & \\
\hline 6 & HHW105 & & & & & * & & & & & & & & & & & & & & & & & & & & \\
\hline 7 & HHW484 & & & & & & * & & & & & & $p$ & & & & & & & & & & & & & $12 p$ \\
\hline 8 & HHW 1126 & & & & & * & & * & & & & & & & & & & & & & & & & & & ins $(5 ; 15)(q 23.2 ; q 22 q 25)$ \\
\hline 9 & HHW509 & & & & & $*$ & & & * & & & & & & & & & & & & & & & & & \\
\hline 10 & HHW862 & & & & & * & & & & * & & & & & & & & & & & & & & & & \\
\hline 11 & HHW983 & & & & & * & & & & & * & & & & & & & & & & & & & & & \\
\hline 12 & HHW 1049 & & & & & * & & & & & & * & & & & & & & & & & & & & & \\
\hline 13 & HHW 271 & & & & & & & & & & & & * & & & & & & & & & & & & & \\
\hline 14 & HHW686 & & & & & * & & & & & & & & * & & & & & & & & & & & & int del(5)(p 15.1p 15.3) \\
\hline 15 & HHW890 & & & & & * & & & & & & & & & * & & & & & & & & & & & \\
\hline 16 & HHW 1125 & & & & & * & & & & & & & & & & * & & & & & & & & & & \\
\hline 17 & HHW967 & & & & & * & & & * & & & & & & & & * & & & & & & & & & \\
\hline 18 & HHW811 & & & & & & & & * & & & & & & & & & * & * & & & & & & & \\
\hline 19 & HHW324 & & & & & & & & & & & & & & & & & & * & & & & & & & \\
\hline 20 & HHW 1113 & * & & & & * & & & & & & & & & & & & & & * & & & & & & del $(5)(q 15 q 21,3)$, tet \\
\hline 21 & HHW690 & & & & & * & & & & & & & & & & & & & & & * & & & & & int del(5)(p 15.1p 15.3$)$ \\
\hline 22 & HHW711 & & & & & * & & & & & & & & & & & & & & & & * & & & & int dell5 $\|_{p} 14.1 \mathrm{p} 15.11$ \\
\hline 23 & HHW441 & & & & & * & & & & & & & & & & & & & & & & & * & & & int del(5)(p $14.1 p 14.3)$ \\
\hline 24 & HHW 1107 & & & & & * & & & & & & & & & & & & & & & & & & * & & $\mid(5,7)(q 35.2, q 22\}$ \\
\hline 25 & HHW212 & & & & & $*$ & & & & & & & & & & & & & & & & & & & * & del $(5) / q ?\}$ \\
\hline 26 & 46. $X Y$ & * & * & * & * & * & * & * & * & * & * & * & * & * & * & * & * & * & * & * & * & * & * & * & * & Total Human \\
\hline
\end{tabular}

FIG. 1. Autoradiogram showing the localization of the p49/p100 locus to human chromosome 10 . The human chromosomes present in each cell line are indicated by asterisks. Human-specific hybridization to a 3.7-kb EcoRI fragment is seen only in lanes 11 (HHW983) and 26 (total human). 


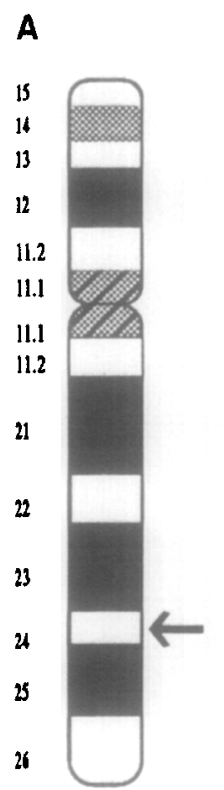

B

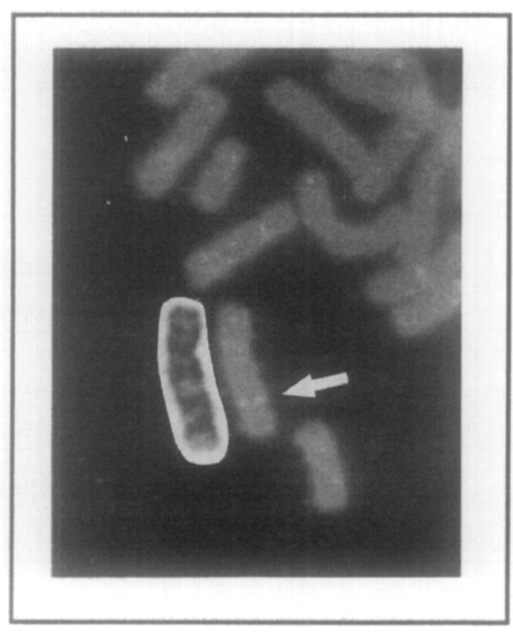

10

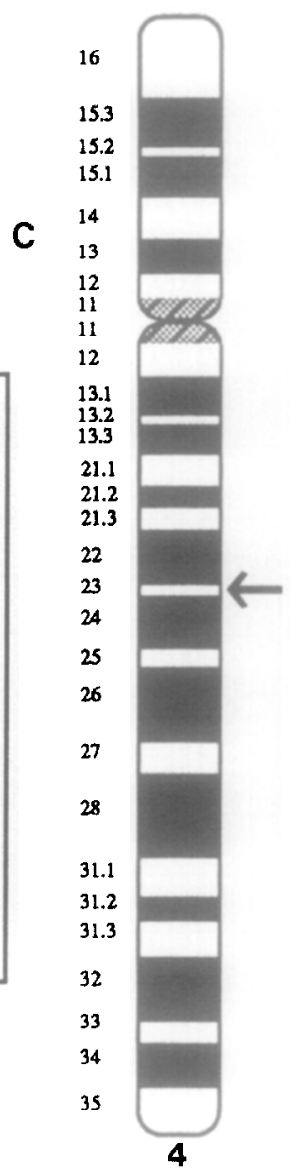

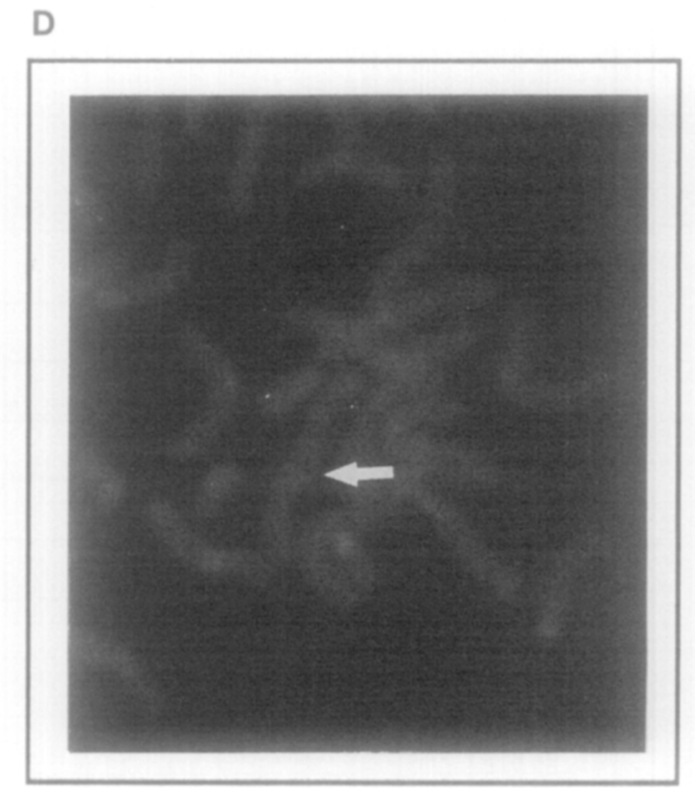

FIG. 2. (A) Arrow indicates localization of the p49/p100 gene to chromosome $10 \mathrm{q} 24$, based on G-banded chromosomes subsequently analyzed by FISH. The probe was the genomic p49/p100 clone, p100.G25. (B) Partial metaphase demonstrating specific hybridization to both chromatids of chromosome 10q24 (arrow) with adjacent G-banded photograph of the same chromosome illustrating its banding pattern. (C) Arrow indicates localization of the p105.G2 genomic clone to chromosome 4q23. (D) Partial metaphase demonstrating specific hybridization of p105.G2 to chromosome 4q23 (arrow).

ization to both chromatids (47 of 50 chromatids). By comparison to the previously G-banded photographs, this specific hybridization was located to chromosome 4q23 (Figs. 2C and D).

\section{DISCUSSION}

In this study, we have determined the chromosomal locations of the human genes NFKB1 and NFKB2 which encode the two alternative DNA binding subunits of $\mathrm{NF}-\kappa \mathrm{B}, \mathrm{p} 105$ and $\mathrm{p} 49 / \mathrm{p} 100 . \mathrm{p} 105$ was assigned to chromosome 4q21.1-q24 and p49/p100 to chromosome 10 by Southern blot analysis of panels of human/Chinese hamster cell hybrids with probes generated from cDNAs. The locations were confirmed by fluorescence in situ hybridization using genomic phage clones and mapped with greater resolution to $4 \mathrm{q} 23$ and 10q24, respectively. Human c-rel has been previously localized to chromosome $2 \mathrm{p} 12-2 \mathrm{p} 13$ by translocation chromosome analysis (Brownell et al., 1988). Taken together, these results show that the chromosomal locations of the known human genes of the $\mathrm{NF}-\kappa \mathrm{B} / \mathrm{rel}$ family are unlinked.
Five independent human cDNAs have been isolated which encode gene products of the NF- $\kappa \mathrm{B} / \mathrm{rel}$ family. A consensus sequence of conserved amino acids within different domains is evident. The amino-terminal domain which has been shown to confer DNA binding and dimerization is found in $\mathrm{p} 49 / \mathrm{p} 100, \mathrm{p} 105, \mathrm{p} 65$, and c-rel. p100 and p 105 are most similar to one another, with $52 \%$ identity compared to conserved amino acids of all family members (26\% identity) in this region.

Though the genes for the human members of the NF$\kappa \mathrm{B} / \mathrm{rel} /$ dorsal family appear to be dispersed throughout the genome, evidence is accumulating that this family may have descended from a common ancestor gene. Comparison of the family members on the nucleotide level shows highly conserved regions within different domains. In the presumed DNA binding and dimerization domain, $\mathrm{p} 49 / \mathrm{p} 100$ and $\mathrm{p} 105$ are $66 \%$ identical at the DNA level, whereas comparing this domain with all family members results only in $25 \%$ identity.

Nonrandom chromosomal abnormalities have been identified in a variety of leukemias, lymphomas, and other malignancies. In acute lymphoblastic leukemia (ALL), the most frequent chromosomal and structural alterations include $\mathrm{t}(8 ; 14), \mathrm{t}(9 ; 22), \mathrm{t}(4 ; 11), 14 \mathrm{q}+, 6 \mathrm{q}-$, 


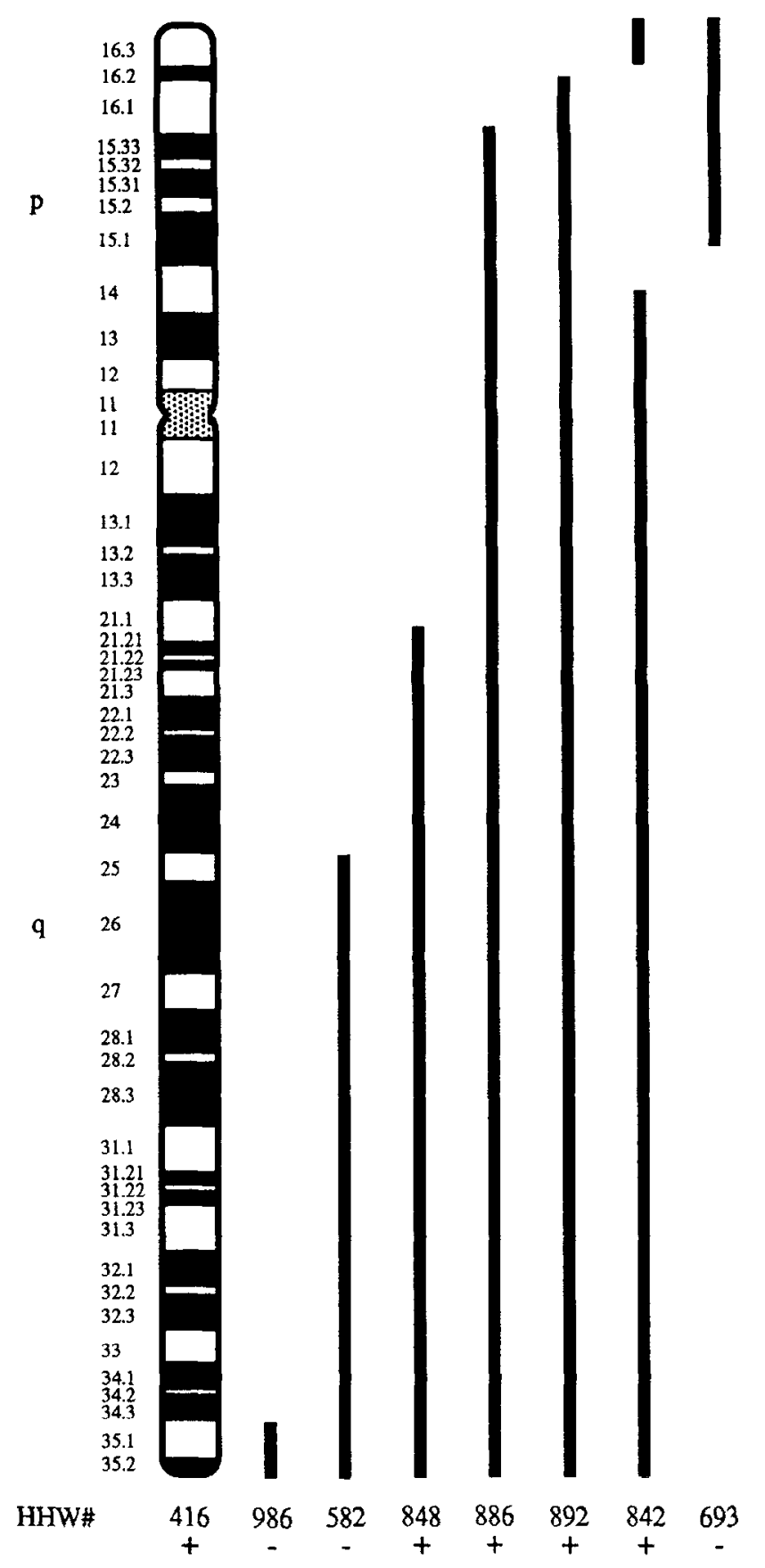

FIG. 3. An idiogram of chromosome 4 is shown on the left. The region of chromosome 4 present in each of the seven cell hybrids is indicated by solid bars on the right, above the hybrid cell line numbers. HHW 416 contains an intact chromosome 4 . The presence or absence of the human-specific HindIII restriction fragment revealed by the $\mathrm{p} 105$ probe is indicated by + or - , respectively.

$t(11 ; 14)$, and $t(10 ; 14)$ (Botti and Verma, 1990). Genes located near or within these breakpoints are thought to be pathogenically involved in the alteration of growth and differentiation.

Although the c-rel gene is associated with malignant transformation in avian species, the role of NF- $\kappa$ B gene products in malignancy is unknown. The translocation $\mathrm{t}(4 ; 11)$ (q21; $\mathrm{q} 23)$ has recently been observed in $8.3 \%$ of patients with ALL (Third International Workshop on Chromosomes in Leukemia, 1981), especially those with congenital leukemia (Prigogina et al., 1979; Arthur et al., 1982). A cell line containing this translocation showed that the cells contain rearranged immunoglobin heavyand light $(\kappa)$-chain genes, providing evidence for B-cell differentiation. However, these cells tested negative for cytoplasmic immunoglobulins (Stong et al., 1985). Since $\mathrm{NF}-\kappa \mathrm{B}$ is a major transcription factor involved in immunoglobin light-chain expression, genetic changes causing alterations of $\mathrm{NF}-\kappa \mathrm{B}$ activity might contribute to this phenotype. Approximately $7 \%$ of T-cell ALLs contain the $t(10 ; 14)(q 24 ; q 11)$ translocation (Dube et al., 1986; Raimondi et al., 1988). Rearrangements of the Tcell-receptor $\delta$ chain on chromosome 14q11 were used to clone breakpoints within chromosome 10q24. Recently, a homeodomain containing gene HOX 11 has been suggested as a candidate gene undergoing deregulation in t(10;14) (Hatano et al., 1991; Lu et al., 1991). Since different breakpoints have been observed in a fragile site at 10q24 (Kagan et al., 1989; Boehm et al., 1989; Zutter et al., 1990; Lu et al., 1990) near the site of $\mathrm{p} 49 / \mathrm{p} 100 \mathrm{NF}$ $\kappa \mathrm{B}$, it remains to be determined whether HOX 11 is the only gene involved in this translocation. Further studies of cells containing these specific chromosome 4 or 10 translocations will determine whether NF- $\kappa$ B plays a causal role in human malignancy.

\section{ACKNOWLEDGMENTS}

We thank Donna Gschwend for typing assistance, Ann Burgess and Edward Hanley for technical expertise, and David Siemieniak for computer analyses. This work was supported in part by National Cancer Institute Grant CA-41183 to P.M., NIH Grant NS-25631 to J.J.W., and NIH Grants AI-26865 and AI-29179 to G.J.N. S.L. and R.M.S. were supported by fellowships from the Deutsche Forschungsgemeinschaft.

Note added in proof. After submission of this paper, the chromosomal lncalization of p105 to 4q23-q25 (Ten et al., 1991) and p100 to $10 \mathrm{q} 24$ (Neri et $a l ., 1991$ ), the latter in association with a B-cell lymphoma translocation, were reported.

\section{REFERENCES}

Altherr, M. R., Smith, B., MacDonald, M. E., Hall, L., and Wasmuth, J. J. (1989). Isolation of a novel mildly repetitive DNA sequence that is predominantly located at the terminus of the short arm of chromosome 4 near the Huntington's disease gene. Genomics 5: $581-588$.

Arthur, D. C., Bloomfield, C. D., Lindquist, L. L., and Nesbit, M. E. (1982). Translocation 4,11 in acute lymphoblastic leukemia: Clinical characteristics and prognostic significance. Blood 59: 96-99.

Baeuerle, P. A., and Baltimore, D. (1988a). Activation of DNA-binding activity in an apparentiy cytoplasmic precursor of the $N F-\kappa B$ transcription factor. Cell 53: 211-217.

Baeuerle, P. A., and Baltimore, D. (1988b). $\mathrm{I}_{\kappa} \mathrm{B}: \mathrm{A}$ specific inhibitor of the NF- $\kappa$ B transcription factor. Science 242: 540-546.

Boehm, 'I., Mengle-Gaw, L., Kees, U. R., Sourr, N., Lavenir, I., Forster, A., and Rabbitts, T. H. (1989). Alternating purine-pyrimidine tracts may promote chromosomal translocations seen in a variety of human lymphoid tumors. EMBO J. 8: 2621-2631.

Böhnlein, E., Lowenthal, J. W., Siekevitz, M., Ballard, D. W., Franza, B. R., and Greene, W. C. (1988). The same inducible protein(s) regulates mitogen activation of both IL- 2 receptor $\alpha$ gene and type I IIIV. Cell 53: 827-836. 
Boshart, M., Weber, F., Jahn, G., Dorsch-Hasler, K., Fleckenstein, B., and Schaffner, W. (1985). A very strong enhancer is located upstream of an immediate early gene of human cytomegalovirus. Cell 41: $521-530$.

Botti, A. C., and Verma, R. S. (1990). The molecular biology of acute lymphoblastic leukemia. Anticancer Res. 10: 519-526.

Bours, V., Villalobos, J., Burd, P. R., Kelly, K., and Siebenlist, U. (1990). Cloning of a mitogen-inducible gene encoding a $k$ B DNAbinding protein with homology to the rel oncogene and to cell-cycle motifs. Nature 348: 76-80.

Brownell, E., Fell, H. P., Tucker, P. W., Geurts van Kessel, A. H. M., Hagemeijer, A., and Rice, N. R. (1988). Regional localization of the human c-rel locus using translocation chromosome analysis. Oncogene 2: 527-529.

Carlock, L. R., Smith, D., Wasmuth, J. J. (1986). Genetic counterselection procedure to isolate interspecific cell hybrids containing single human chromosomes: Construction of cell hybrids and recombinant DNA libraries specific for human chromosome 3 and 4. Somat. Cell Mol. Genet. 12: 163.

Dube, J. D., Raimondi, S. C., Pi, D., and Kalousik, D. K. (1986). A new translocation, $\mathbf{t}(10 ; 14)(\mathrm{q} 24 ; \mathrm{q} 11)$, in T cell neoplasia. Blood 67: 1181-1184.

Feinberg, A. P., and Vogelstein, B. (1983). A technique for radiolabeling DNA restriction endonuclease fragments to high specific activity. Anal. Biochem. 132: 6-13.

Ghosh, S., Gifford, A. M., Riviere, L. R., Tempst, P., Nolan, G. P., and Baltimore, D. (1990). Cloning of the p50 DNA binding subunit of NF-kB: Homology to rel and dorsal. Cell 62: 1019-1029.

Griffin, E. G., Leung, K., Folks, T. M., Kunkel, S., and Nabel, G. J. (1989). Activation of HIV gene expression during monocyte differentiation by induction of NF-kB. Nature 339: 70-73.

Hatano, M., Roberts, C. W. M., Minden, M., Christ, W. C., and Korsmeyer, S. J. (1991). Deregulation of a homeobox gene, HOX11, by the $\mathrm{t}(10 ; 14)$ in T cell leukemia. Science 253: 79-82.

Israël, A., Le Bail, O., Hatat, D., Kieran, M., Logeat, F., Wallach, D., Fellous, M., and Kourilsky, P. (1989). TNF stimulates expression of $\mathrm{MHC}$ class I genes by inducing an NF- $\mathrm{B}$-like enhancer binding activity which displaces constitutive factors. EMBO J. 8: 37933800.

Kagan, J., Finger, L. R., Letofsky, J., Finan, J., Nowell, P. C., and Croce, C. M. (1989). Clustering of breakpoints on chromosome 10 in acute T-cell leukemias with the $t(10 ; 14)$ chromosome translocation. Proc. Natl. Acad. Sci. USA 86: 4161-4165.

Kieran, M., Blank, V., Logeat, F., Vandekerckhove, J., Lottspeich, F., Le Bail, O., Urban, M., Kourilsky, P., Baeuerle, P. A., and Israël, A. (1990). The DNA binding subunit of NF- $-\mathrm{B}$ is identical to factor KRF1 and homologous to the rel oncogene product. Cell 62: 10071018.

Klever, M., Grond-Ginsbach, C., Schertan, H., and Schroeder-Kurth, T. M. (1991). Chromosomal in situ suppression hybridization after Giemsa banding. Hum. Genet. 86: 484-486.

Lenardo, M. J., and Baltimore, D. (1989). NF-kappa B: A pleiotropic mediator of inducible and tissue-specific gene control. Cell 58: 227229.

Leung, K., and Nabel, G. (1988). HTLV-1 transactivator induces interleukin-2 receptor expression through an $\mathrm{NF}-\kappa \mathrm{B}$-like factor. $\mathrm{Na}$ ture 333: 776-778.

Lu, M., Dube, I., Raimondi, S., Carrol, A., Zhao, Y., Minden, M., and Sutherland, P. (1990). Molecular characterization of the $t(10 ; 14)$ translocation breakpoints in T-cell acute lymphoblastic leukemia: Further evidence for illegitimate physiological recombination. Genes Chromosom. Cancer 2: 217-222.

Lu, M., Gong, Z., Shen, W., and Ho, A. D. (1991). The tcl-3 proto-oncogene altered by chromosomal translocation in T-cell leukemia codes for a homeobox protein. EMBO J. 10: 2905-2910.

Nabel, G., and Baltimore, D. (1987). An inducible transcription factor activates expression of human immunodeficiency virus in T-cells. Nature 326: 711-713

Neri, A., Chang, C.-C., Lombardi, L., Salina, M., Corradini, P., Maiolo, A. T., Chaganti, R.S. K., and Della-Favera, R. (1991). B cell lymphoma-associated chromosomal translocation involves candi date oncogene lyt-10, homologous to NF- $\mathrm{B}$ p50. Cell 67: 10751087.

Osborn, L., Kunkel, S., and Nabel, G. J. (1989). Tumor necrosis factor $\alpha$ and interleukin 1 stimulate the human immunodeficiency virus enhancer by activation of the nuclear factor $\kappa \mathrm{B}$. Proc. Natl. Acad. Sci. USA 86: 2336-2340.

Pinkel, D., Straume, T., and Gray, J. W. (1986). Cytogenetic analysis using quantitative, high-sensitivity, fluorescence hybridization. Proc. Natl. Acad. Sci. USA 83: 2934-2938.

Prigogina, E. L., Fleischman, E. W., Puchkova, G. P., Mujukova, S. A., Balakirev, S. A., Frenkel, M. A., and Khuatova, N. V. (1979). Chromosomes in acute leukemia. Hum. Genet. 53: 5-16.

Raimondi, S. C., Behm, F. G., Roberson, P. K., Pui, C. H., Rivera, G. K., Murphy, S. B., and Williams, D. L. (1988). Cytogenetics of childhood T-cell leukemia. Blood 72: 1560-1566.

Ruben, S., Dillon, P., Schreck, R., Henkel, T., Chen, C.-H., Maher, M., Baeuerle, P., and Rosen, C. (1991). Isolation of a rel-related human cDNA that potentially encodes the $65 \mathrm{kd}$ subunit of NF- $\mathrm{B}$. Science 251: 1490-1493.

Ruben, S., Poteat, H., Tan, T.-H., Kawakami, K., Roeder, R., Haseltine, W., and Rosen, C. A. (1988). Cellular transcription factors and regulation of IL-2 receptor gene expression by HTLV-1 tax gene product. Science 241: 89-92.

Ryseck, R. P., Bull, P., Takamiya, M., Bours, V., Siebenlist, U., Dobrzanski, P., and Bravo, R. (1992). Rel-B, a new rel family transcription activator that can interact with p50-NF-KB. Mol. Cell. Biol. 12: 674-684.

Scherer, L. J., McPherson, J. D., Wasmuth, J. J., and Marsh, J. L. (1992). Human Dopa decarboxylase: Localization to chromosome 7p11 and characterization of hepatic cDNAs. Genomics 13: 469171.

Schmid, R. M., Perkins, N. D., Duckett, C. S., Andrews, P. C., and Nabel, G. J. (1991). Cloning of a NF- $\kappa$ B subunit which stimulates HIV transcription in synergy with p65. Nature 352: 733-736.

Sen, R., and Baltimore, D. (1986a). Multiple nuclear factors interact with the immunoglobulin enhancer sequences. Cell 46: 705-716.

Sen, R., and Baltimore, D. (1986b). Inducibility of $\kappa$ immunoglobulin enhancer-binding protein $\mathrm{NF}-\kappa \mathrm{B}$ by a posttranslational mechanism. Cell 47: 921-928.

Smith, G. E., and Summers, M. D. (1980). The bidirectional transfer of DNA and RNA to nitrocellulose or diazobenzyloxymethyl-paper. Anal. Biochem. 109: 123-129.

Stong, R. C., Korsmeyer, S. J., Parkin, J. L., Arthur, D. C., and Kersey, J. H. (1985). Human acute leukemia cell line with the $t(4 ; 11)$ chromosomal rearrangement exhibits $B$-lineage and monocytic characteristics. Blood 65: 21-31.

Tabas, J. A., Zasloff, M., Wasmuth, J. J., Emanuel, B. S., Altherr, M. R., McPherson, J. D., Wozney, J. M., and Kaplan, F. S. (1991). Bone morphogenetic protein: Chromosomal localization of the human genes for BMP1, BMP2A, and BMP3. Genomics 9: 283-289.

Ten, R. M., Paya, C. V., Israël, N., Le Bail, O., Mattei, M.-G., Virelizier, J.-L., Kourilsky, P., and Israël, A. (1992). The characterization of the promoter of the gene encoding the $\mathrm{p} 50$ subunit of NF- $\kappa \mathrm{B}$ indicates that it participates in its own regulation. EMBO $J$. 11: 195203.

Third International Workshop on Chromosomes in Leukemia (1981). Cancer Genet. Cytogenet. 4: 95-142.

Zutter, M., Hockett, R. D., Robert, C. W. M., McGuire, E. A., Bloomstone, J., Morton, C. C., Deaven, L. L., Christ, W. M., Carroll, A. J., and Korsmeyer, S. J. (1990). The $t(10 ; 14)(\mathrm{q} 24 ; \mathrm{q} 11)$ of T-cell acute lymphoblastic leukemia juxtaposes the T-cell receptor with TCL3, a conserved and activated locus at 10q24. Proc. Natl. Acad. Sci. USA 87: $3161-3165$. 